he was a professor of anthropology, a fellow of Pierson College, a research associate of the Peabody Museum and chairman of the Department of Anthropology. These were a few of the academic evidences of a highly successful career, which had been remarkably steady in its progress and exceptionally fruitful both in scholarship and in personal influence.

Almost from the first, Bennett had devoted himself to the pre-history of South America. With the exception of two early apprentice essays, one on the culture of the Tarahumara of northern Mexico and the other on the archæology of the Hawaiian Islands, his research was directed almost exclusively to South American archæology. His first undertakings in this area were begun while on the staff of the American Museum of Natural History, where he remained for seven years. These were rewarding years, during which he laid the groundwork of his own subsequent researches which very largely were responsible in establishing Peruvian archæology on the sound footing it now occupies.

It was during this period that he made the first stratigraphic excavations in Bolivia, working at the famous site of Tiahuanaco. For this fundamental work he was decorated afterwards by the Bolivian Government. While still at the American Museum of Natural History he carried out significant excavations in the north coastal area of Peru and in Venezuela. The former led to a re-definition of the chronological sequences of Peruvian archæology and the latter provided the first systematic archæological data for Venezuela.

On leaving the American Museum of Natural History in 1938, he moved to the University of Wisconsin, attracted there by the opportunity to teach. In 1940 he was invited to Yale, where he remained until his death. During his association with Yale, Bennett was able, despite his teaching and administrative duties, to continue his archæological research. One of his outstanding achievements in this period of his career was the part he played in organizing the Virú Valley project. Out of this large co-operative venture came his fine study of the Gallinazo culture. The last archæological enterprise on which Bennett was engaged is not yet published, but it is in the press and is concerned with the problem of the development of coastal Tiahuanaco culture.

The confidence of his fellow anthropologists that Bennett enjoyed and his reputation for sound counsel were reflected in the numerous posts to which he was elected and appointed in professional societies and organizations. He was president of the American Anthropological Association in 1952, and executive secretary of the Joint Committee on Latin American Studies from 1942 to 1944 . He was chairman of Yale's Area Studies Executive Committee, and he was active in the Social Science Research Council.

Wendell Bennett was born in the Middle Westin Marion, Indiana-m August 17, 1905, the son of William Rainey Bennett, a minister and lecturer. His schooling was in Chicago and his university career at the University of Chicago, where he was an excellent scholar as well as an exceptional athlete. In 1925 he married Hope Ranslow and from this marriage two daughters, Lucy and Martha, were born. As a person Bennett possessed great charm and warmth. He had a fine gift for friendship to which all varieties of people responded. It was, in fact, this lovable quality which contributed so greatly to his success in organizing. As an archæologist he was rigorous and critical, demanding the highest standards of professional competence from himself and from his colleagues. His contributions have been fundamental in advancing our knowledge of South American prehistory.

$\mathrm{He}$ will be mourned by a wide circle of friends and colleagues for the feeling of personal loss that the departure of a generous spirit always leaves, and for the sense of loss that the interruption of a full career always implies. Harry I. Shapiro

\section{Prof. N. D. Zelinskii}

Nicholas Drmitrivich Zelinskix was born on February 6, 1861, in Tiraspol in the Province of Kherson. He received his school training locally and in Odessa, and afterwards went to the University of Novorossisk. Later he studied in Leipzig and in Göttingen, working there in the laboratory of Victor Meyer. In 1888 he obtained his master's degree and was appointed lecturer at his old University of Novorossisk. There he presented first his master's thesis dealing with thiophene chemistry in 1889 , and two years later a thesis for his doctorate on the stereoisomers of saturated carbon compounds.

Zelinskii was appointed adjunct professor in Moscow in 1893 and, except for six years spent at St. Petersburg, remained there until his death on July 31 of this year. The six years interruption occurred during 1911-17, when in company with a hundred other professors and teachers he resigned as a protest against the dismissal of the entire administration staff of the University of Moscow by the Ministry of Education.

Although Zelinskii's contributions to chemical knowledge ranged over a vast field, including heterocyclic derivatives, protein hydrolysis and the syn. thesis of $\alpha$-amino-acids, his chief contributions were to hydrocarbon chemistry. In 1891 he prepared the first synthetic naphthene, 1.3-dimethylcyclohexane, and showed its close relationship with the octa. naphthene of Caucasian petroleum. This, and later work on the synthesis of saturated cyclic hydrocarbons, ranging from simple to complex polycyclic systems, brought with it an interest in petroleum and the terpenes. As early as the 'nineties he took an active part in the operation of a plant to prepare aromatic hydrocarbons by pyrolysis of petroleum, and thus was among the earliest pioneers of petrochemicals. Later, he showed that aromatics could be more conveniently produced from petroleum by catalytic dehydrogenation of naphthenes than by pyrolysis. This resulted from his discovery in 1911 that cyclohexane derivatives can be converted to aromatic hydrocarbons by passage over a suitable catalyst, an observation which led to the establish. ment of a school of contact catalysis under his leadership. His contributions in this field were immense; he was the first to use platinum metals as hydrogenation/dehydrogenation catalysts and to differentiate between $\mathrm{C}_{5}$ - and $\mathrm{C}_{6}$-naphthenes by their behaviour on dehydrogenation - $-\mathrm{a}$ valuable tool in his investigation of the composition of petroleum. Isomerization, desulphurization, cyclization and many other processes of technical interest owe much to his pioneer efforts. His interests included also the origin of petroleum, where no doubt his early association, in 1889 , with an expedition to the Black Sea, which proved the bacterial origin of the hydrogen 
sulphides present in its depths, encouraged his views as to the organic origin of petroleum, views which he supported with experimental work on the thermal decomposition of sapropelite, a substance of algal origin deposited in vast quantities on the shores of Lake Balkhash.

Zelinskii's first paper appeared in the Journal of the Russian Chemical Society when he was a student in 1884, and in the sixty-seven years that followed he published more than five hundred others, including many with some hundred and forty of his students. On three occasions he was awarded the highest honour of the U.S.S.R.- the Order of Lenin. He also received numerous other honours from the government of the U.S.S.R., including the title of Hero of Socialist Labour.
WE regret to announce the following deaths :

Dr. W. R. Cunningham, librarian of the University of Glasgow and keeper of the Hunterian books and manuscripts, on October 25, aged sixty-three.

Prof. Colin G. Fink, recently head of the Division of Electrochemistry, Columbia University, and president in 1917 of the Electrochemical Society in the United States, aged seventy-two.

Mr. H. J. Hornby, chairman of A. Gallenkamp and Co., Ltd., and chairman during 1941-43 of the British Laboratory Ware Association, Ltd., on November 2, aged sixty-eight.

Prof. E. Piwowarsky, professor of general metallurgy and director of the Institute for General Metallurgy and Foundry-work in the Technical High School, Aachen, aged sixty-one.

\section{NEWS and VIEWS}

Nobel Prize for Physics for 1953 :

Prof. F. Zernike

THE work of Prof. F. Zernike, who has been awarded the Nobel Prize for Physics for 1953, includes many distinguished contributions in fields other than optics, but his successes in this branch of physics alone have been sufficient to earn him an international reputation. His serious interest in optics seems to have started some twenty years ago. In 1934 he published a diffraction theory of the Foucault knife-edge test for the figure of astronomical telescope mirrors. This work was notable on two counts : for the discovery of the so-called circle polynomials (now widely, and rightly, known as Zernike polynomials), and for the introduction of the method of phase contrast. Almost immediately Zernike realized that the same method could be used in the other extreme of optical instruments, namely, the microscope. The fruitful results of this invention, especially in biological work, are both sufficiently widely known and appreciated to require no comment. This being so, it is easy to forget Prof. Zernike's other contributions to optics. His work, and that of his pupils, on the diffraction theory of aberrations, the experimental study of these effects, the use of the method of the "coherent background' in diffraction, and the theory of partial coherence, equally constitute an outstanding contribution to our present knowledge of optics. Prof. Zernike is well known in Britain. He has delivered the Thomas Young Oration of the Physical Society, and in 1952 he was awarded the Rumford Medal of the Royal Society.

\section{Royal Society: Award of Royal Medals}

H.M. The QUEen has been graciously pleased to approve recommendations made by the Council of the Royal Society for the award of the two Royal Medals for 1953 as follows : to Sir Paul Fildes, O.B.E., F.R.S., for his classical researches on growth factors for bacteria and for laying the foundation of work leading to a rational approach to chemotherapy; to Prof. N. F. Mott, F.R.S., for his eminent work in the field of quantum theory and particularly in the theory of metals.

Metrology at the National Physical Laboratory, Teddington: Mr. F. H. Rolt, O.B.E.

Mr. F. H. RoLT, who has retired from his post as the superintendent of the Metrology Division of the
National Physical Laboratory, Teddington, has been associated since 1912 with the laboratory's work in the field of engineering metrology and standardization. During the First World War the widespread application by the Ministry of Munitions of the principles of interchangeable manufacture placed enormous demands upon the Laboratory for verifications of reference standards and gauges, and for the development of methods and apparatus for the precise measurement of dimension and shape. Appreciation of the economic advantages of quantity production gave rise later on to studies in the Metrology Division of the basic principles underlying suitable design of interchangeable components and the efficient control of such products by accurate gauging or measurement during manufacture. Mr. Rolt was responsible for the prosecution of many of these studies, and for several developments of methods and apparatus now widely adopted in the practice of engineering inspection. His "Gauges and Fine Measurements", published in two volumes in 1929, achieved world-wide renown and appreciation. In 1941 he was seconded to the Ministry of Supply (Machine Tool Control), in which he served until the end of the Second World War, first as director of gauges and measuring instruments and later as director of jigs, tools and gauges. For these services he was made O.B.E. He succeeded Mr. J. E. Sears as superintendent of the Metrology Division in 1946. Mr. Rolt has contributed much to the work of numerous committees of the British Standards Institution and of other organizations, both national and international, concerned with the establishment of engineering standards. He took a leading part in the post-war American-BritishCanadian conferences, one of which led to the adoption of the unified screw thread. He is also keenly interested in the education of engineering students and apprentices, and was instrumental in introducing engineering metrology as a subject for the Higher National Certificates in mechanical and production engineering.

Dr. H. Barrell

Mr. Rout is being succeeded by Dr. H. Barrell. Dr. Barrell was educated at the Royal Grammar School, High Wycombe, and the Royal College of Science, London, where he studied physics and later specialized in spectroscopy. He joined the staff of the National Physical Laboratory in 1923, and was associated 